\title{
Environmental change: prospects for conservation and agriculture in a southwest Australia biodiversity hotspot
}

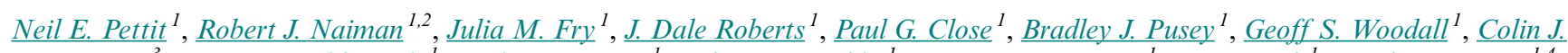

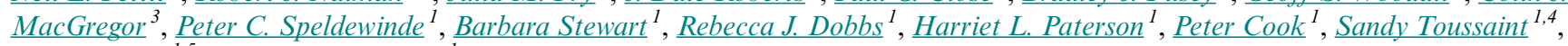 \\ Sarah Comer ${ }^{1,5}$ and Peter M. Davies ${ }^{1}$
}

\begin{abstract}
Accelerating environmental change is perhaps the greatest challenge for natural resource management; successful strategies need to be effective for decades to come. Our objective is to identify opportunities that new environmental conditions may provide for conservation, restoration, and resource use in a globally recognized biodiversity hotspot in southwestern Australia. We describe a variety of changes to key taxonomic groups and system-scale characteristics as a consequence of environmental change (climate and land use), and outline strategies for conserving and restoring important ecological and agricultural characteristics. Opportunities for conservation and economic adaptation are substantial because of gradients in rainfall, temperature, and land use, extensive areas of remnant native vegetation, the ability to reduce and ameliorate areas affected by secondary salinization, and the existence of large national parks and an extensive network of nature reserves. Opportunities presented by the predicted environmental changes encompass agricultural as well as natural ecosystems. These may include expansion of aquaculture, transformation of agricultural systems to adapt to drier autumns and winters, and potential increases in spring and summer rain, carbon-offset plantings, and improving the network of conservation reserves. A central management dilemma is whether restoration/preservation efforts should have a commercial or biodiversity focus, and how they could be integrated. Although the grand challenge is conserving, protecting, restoring, and managing for a future environment, one that balances economic, social, and environmental values, the ultimate goal is to establish a regional culture that values the unique regional environment and balances the utilization of natural resources against protecting remaining natural ecosystems.
\end{abstract}

Key Words: adaptive management; agriculture and conservation; biodiversity; climate change; land-use change; southwest Australia.

\section{INTRODUCTION}

Environmental change is inevitable. The pace of environmental change, whether from climate, land use, proliferation of artificial chemicals, human behaviors, or other drivers, is accelerating (WHO 2015). Although there is an urgent need to document trends, as well as the consequences for the environment and society, there are equally urgent needs for scientists, managers, and communities to form partnerships in natural resource management. Those partnerships face three critical challenges: (1) to predict how the anticipated changes will unfold on the landscape (Lester et al. 2014); (2) to identify strategies for conserving regionally important biota, ecosystems, and ecological processes; (3) the need to recognize unique opportunities that new environmental conditions provide for conservation, for rehabilitation/restoration of altered ecosystems, and, as well, for resource use. Collectively, these needs present a great challenge for natural resource management in that, to be successful, strategies developed and acted upon today need to be effective for decades to come.

Recently agriculture and conservation biology have begun to address the first two needs. This is primarily because the success of both disciplines depends on an ability to anticipate future conditions. The third need has received some attention in agriculture but relatively little attention in conservation biology. Only a small percentage of articles in the primary literature describing ongoing environmental changes seek to identify emerging conservation opportunities associated with environmental change (Lockwood et al. 2014), and most opt to focus on the loss of ecosystem diversity and function, system-scale resilience, and nature's benefits. That is not to say that there is little to be concerned about - quite the opposite - yet environmental change also creates intriguing opportunities associated with regionally based natural resources. These opportunities focus on the interaction between the social-economic and natural systems to develop adaptive capacity (Allison and Hobbs 2004, Mawdsley et al. 2009, Barthel et al. 2013).

Southwestern Australia, including the South Coast Region (Fig. 1), provides an excellent example of how environmental change offers interesting opportunities for integrating divergent land uses with the conservation and use of natural resources. Mediterranean ecosystems are considered especially sensitive to synergies between all drivers of global change (Sala et al. 2000). The regionally high biodiversity and levels of endemism (3950 plant spp, $49 \%$ endemic) coupled with extensive clearing means that the South Coast Region is a world-recognized hotspot of biodiversity (Myers et al. 2000). The biodiversity and endemism are considered to be due to its Gondwanan affinities, weathered ancient landscape (unglaciated since the Permian), and a long period of isolation (Hopper 2009). The region supports a mixture of relict and modern species, and possesses a vast diversity of habitats that span from wet sclerophyll tall forest in the west to semiarid woodlands in the east, many of which have been converted to agricultural and urban uses since the arrival of Europeans in 1826. This region has a wealth of faunal and floral

${ }^{1}$ Centre of Excellence in Natural Resource Management, The University of Western Australia, ${ }^{2}$ University of Washington, ${ }^{3}$ College of Marine \& Environmental Sciences, James Cook University, ${ }^{4}$ School of Social and Cultural Studies, The University of Western Australia, ${ }^{5}$ Department of Parks and Wildlife 
diversity including ancient lineages with Gondwanan and Laurasian relationships through to currently evolving taxa showing high levels of intraspecific diversity (Hopper and Gioia 2004, Rix et al. 2014). These patterns of diversity coexist with a variety of intensive land-use practices from broad acre farming, mining, and intensive forestry to managed native forests, and persist in both modified landscapes and in small and large areas of the conservation estate. The net result is that the region now consists of a mosaic of intact and highly altered ecosystems.

Fig. 1. Southwest of Western Australia indicating the rainfall gradients and the boundaries of the South Coast region.

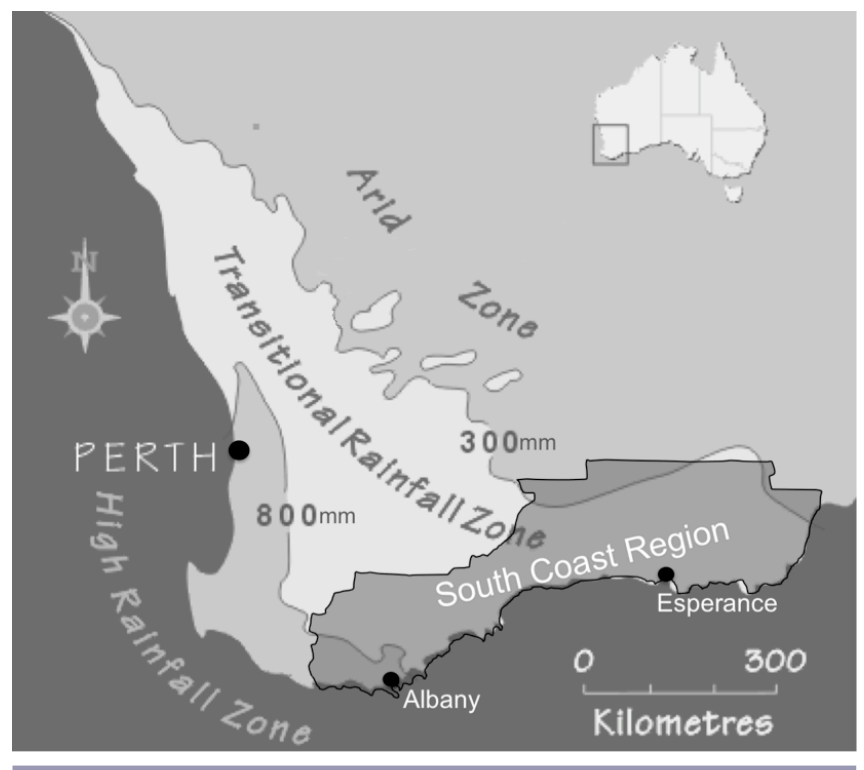

Southwestern Australia has already undergone significant climate change with drying and warming (CSIRO 2007) with a further $0.2^{\circ} \mathrm{C}$ temperature increase per decade predicted over the next 30 years (Hennessy et al. 2007, Davies 2010). These are not static landscapes; although tectonically stable with an ancient, underlying granite shield, the region has undergone extensive historical climate variation from rainforest and relatively high temperatures in the Miocene, followed by drying, cooling, and rapidly varying climates in the Pliocene, and finally by three major climatic fluctuations, characterized by lower rainfall and lower temperatures, in the Pleistocene (Rix et al. 2014). These major climate changes are associated with ongoing periods of generation of phylogenetic diversity in the flora and fauna (Rix et al. 2014) suggesting climate change may not necessarily be catastrophic for biota in the South Coast Region. However, the accelerated pace of present climate change, unprecedented in geological time (IPCC 2014), resulting in increases in temperature, along with concomitant decreases in rainfall and continued land transformation, is likely to detrimentally affect native biodiversity. However, we also recognize not all climate change affects are directional. Moritz and Agudo (2013) reported range movements of plants and animals on mountains during rising temperatures that were counterintuitive: ranges shifted downslope and sideways indicating not all distributions are climate limited. In a similar vein two recent studies have suggested biota might use the inherent, small-scale variability in ecological systems to avoid modeled climate shifts (e.g., Scheffers et al. 2013, 2014). Southwestern Australia now consists of a mosaic of largely intact to highly altered ecosystems, with a long, complex evolutionary history offering a useful setting to examine opportunities for integrating resource use and conservation at a bioregional scale (Cheng et al. 2003, Campbell 2008, Donovan et al. 2009).

The unique opportunities presented by environmental change encompass agricultural as well as natural ecosystems. The challenge in biodiversity hotspots globally is to manage conservation of existing diversity, manage for ongoing evolution, and to integrate the social and political environment into these processes. Southwestern Australia can be a model for developing those approaches and this paper focuses on a subset of that region, the south coast Natural Resource Management (NRM) region (Fig. 1, hereafter SCR). One of the central dilemmas is whether restoration/conservation efforts should have a commercial or biodiversity focus and, can these be integrated? The grand challenge is conserving, protecting, restoring, and managing for a future environment that balances economic, social, and environmental values. Biodiversity is a major environmental indicator that continues to decline worldwide and, in biodiversity hotspots such as the SCR, there needs to be a special focus on devising ways of living sustainably with biodiversity. The ultimate goal is to establish a regional culture that values the regional environment and balances the utilization of natural resources with protecting the natural ecosystems. Our objective is to identify opportunities that emerging environmental conditions may provide for conservation, restoration, and future resource use, using the SCR as a case study.

\section{THE SOUTH COAST REGION (SCR)}

\section{Climate}

The SCR has a Mediterranean climate with cool wet winters and temperate to hot dry summers with average annual rainfall ranging from $300 \mathrm{~mm}$ in the north and east to $1200 \mathrm{~mm}$ in the southwest (Fig. 1) There is also a gradient in mean annual evaporation from northeast to southwest. The SCR can be divided into two broad climatic zones: a western, cooler, high rainfall zone (greater than $800 \mathrm{~mm}$ ) and a warmer lower rainfall zone, sometimes referred to as the transitional rainfall zone (300-800 $\mathrm{mm})$. These broad zones are differentiated in terms of flora (Hopper and Gioia 2004), aquatic systems (Stewart 2009), and land use (Hill et al. 2005). Both extend north, outside the SCR of our focus. The SCR has seen frequent past oscillations in climate with drier, warmer, and wetter periods but a broad trend of increasing aridity during the later Tertiary (Byrne 2008).

\section{Physical characteristics}

The SCR is one of 56 natural resource management regions in Australia developed under agreements between state, territory, and federal governments. These regions are based on catchments or bioregions and are well placed to plan for adaptation to landuse and climate-change effects (Campbell 2008). The South Coast bioregion's boundaries are based broadly on the catchments of southerly flowing rivers but also include some internally drained areas in the north and northeast. Topography, soils, and microclimate are locally diverse but soils are generally nutrient deficient and highly weathered (Hopper and Gioia 2004). The 
geology of the SCR is considered a result of Precambrian collisions between continents forming the Albany-Fraser orogen (1300-1100 million years ago [Mya]) and the rifting of Antarctica from Australia (80-35 Mya). The northern part of the region also includes the ancient Yilgarn craton (2700-2600 Mya; Myers 1990). In general, the ancient landscape is of low relief with a few punctuated uplands; the highest peak is $1095 \mathrm{~m}$.

The replacement of deep rooted natural vegetation with shallow rooted annual crops and pastures has allowed greater infiltration of rainwater and a subsequent rise in the water table, concentrating soil-stored salts near the surface (McFarlane and George 1992, George et al. 1997). This process has led to increased salinity of waterways and surface soils in lower parts of the landscape. This secondary salinization is dependent on the extent of clearing, topography, and rainfall (Mayer et al. 2005). With changing climatic conditions, e.g., temperatures increases and rainfall decreases, there is potential for positive and negative effects on secondary salinization. If salinity increases it will have a dramatic negative effect on biodiversity and future land-use activities, especially for local farmers and nearby communities (Beresford et al. 2001).

Many larger rivers in the region have headwaters in the warmer, lower rainfall, lower relief, northern parts of the SCR (or further north) with the southern reaches in areas that are cooler, and have higher rainfall and higher relief. There are pockets of fresh, coastal groundwater but most inland groundwater is either brackish or highly saline contributing to the salinity of the larger river systems. Flow regimes are highly distinctive being almost exclusively within the predictable winter, intermittent category defined by Kennard et al. (2010), which is largely confined to southwest Australia. Within the region, there is a distinct longitudinal gradient in river flows: eastern catchments are ephemeral and characterized by unpredictable and intermittent periods of a seasonally high flow, whereas catchments in the west are mostly perennial, strongly seasonal, and predictable (Close 2007).

\section{Biotic characteristics}

The SCR forms part of the Southwest Australian Floristic Region that is recognized as a global biodiversity hotspot because of the concentration of endemic species and loss of habitat (Myers et al. 2000, Mittermeier et al. 2004). Major taxa in the SCR, including the level of endemism, vulnerability, and the major stressors, are generally well known (Table 1). This list provides an indication of the particular level of SCR biodiversity and the need for protection and conservation, especially of the many endemic species. Although knowledge of basic biology in the region is reasonably thorough there are still many gaps in understanding of taxonomy of many groups, particularly terrestrial invertebrates, although this has been rapidly improving in recent years (Danks et al. 2011, Rix et al. 2014).

There are 812 genera and 232 families of plants (Gioia 2010) in southwestern Australia, with unusually high levels of endemism, many species with restricted distributions, and a significant number of species and subspecies yet to be described (Hopper and Gioia 2004). The main threats to the remaining native flora and fauna are plant pathogens such as Phytophthora cinnamomi, feral animals and introduced plants, habitat fragmentation, altered hydrology and salinity, and inappropriate fire regimes (see also Table 1). Approximately $27 \%$ of the region is in conservation reserves (Danks et al. 2011), which makes the protection of potentially vulnerable taxa outside this reserve system difficult (Hopper 2009). Nine identified vegetation types (Beard 1980) have been identified as having $10 \%$ or less of their original (preEuropean) extent remaining, and 20 others have less than $30 \%$ remaining (Danks et al. 2011). This highlights the importance of the conservation of areas of native vegetation for the plant communities as well as the fauna habitat they represent. For southwestern Australia broadly, there are many Gondwanan relics and levels of endemism are high for most taxa, although this is variable across taxonomic groups, e.g., $2 \%$ of 300 bird spp, $93 \%$ of 30 amphibians spp, 49\% of 3950 spp of flowering plants (Hopper and Gioia 2004, Davies and Stewart 2013), with a high proportion of those endemics occurring in or restricted to the SCR, e.g., 22 of 30 frog species.

\section{Anthropogenic landscape change}

Human modification of the SCR occurred during two distinct periods. The indigenous occupants of the region, who broadly identify as Noongar (sometimes spelt Nyungar) have a suite of stories telling of the creation of the landscape and the relationship between themselves and the Dreaming, through the practice of customary law and religion. This relationship includes peoples' interactions with, and obligations toward, the protection of lands and waters, and all interrelated species. Indigenous groups managed the landscape through their "Dreaming ecology," which included the use of fire to manage ecosystems (Collard 2006). Later, European settlement of the SCR substantially changed the landscape. Settlement started in 1829 but the most extensive clearance of native vegetation occurred in the 20th century with over 50\% occurring after World War II (Wilkins et al. 2006). Aboriginal groups were severely disenfranchised by these developments (Beresford et al. 2001). The historic 1992 Mabo Decision and the subsequent Native Title Act (1994) with its potential to develop a land claims process for indigenous groups, provides a possibility to directly involve the indigenous Noongar people in natural resource management of their ancestral lands.

\section{NATURAL RESOURCE MANAGEMENT SCENARIOS FOR A 2050 FUTURE}

Because southwestern Australia is contained by the ocean (south and west) and desert (northeast) it has been identified as the Mediterranean biome likely to undergo the biggest contractions in area and, therefore, one of the highest priorities for climate change adaptation (Klausemeyer and Shaw 2009). Biodiversity in the SCR is already subject to a range of threatening processes including removal of native vegetation, spread of dieback disease, non-native weeds and feral animals, spread of pollutants, salinizing lands, and hydrologic change. These are expected to interact with climate change in complex ways (Horwitz et al. 2008). Increases in temperature, decreases in rainfall and greater seasonal variation will affect species and communities to various degrees (Davies 2010, Stewart et al. 2013). For instance, paleoclimate records reveal drier periods in the past and therefore some species already may have the adaptive capacity to survive declining rainfall (Byrne 2008), while others may be vulnerable.

The climate of SCR has already changed considerably with substantial decline in rainfall and subsequent stream flows since 1965 (Davies 2010, Australian Government 2015), with patterns 
Table 1. Overview of known major taxa identified in the South Coast Region of Western Australia. For this list no attempt was made to distinguish current distribution from historical records.

\begin{tabular}{|c|c|c|c|c|c|c|}
\hline$\overline{\text { Taxa }}$ & $\begin{array}{l}\text { South Coast } \\
\text { Species }\end{array}$ & $\begin{array}{l}\text { Non-native } \\
\text { Species }\end{array}$ & $\begin{array}{l}\text { Endemic to } \\
\text { South Coast }\end{array}$ & Threatened $^{\dagger}$ & Principal Stressors & References/ Notes \\
\hline $\begin{array}{l}\text { Terrestrial } \\
\text { invertebrates } \\
\text { (where known) }\end{array}$ & $\sim 175$ & $-{ }^{*}$ & 115 & $\sim 7 \mathrm{spp}$ & Secondary salinization & $\begin{array}{l}\text { Many Gondwanan relics; } \\
\text { Gilfillan 2000, Framenau et } \\
\text { al. 2008, Danks et al. 2011; M. } \\
\text { S. Harvey and M. C. Leng, } \\
\text { unpublished data. }\end{array}$ \\
\hline Freshwater & 439 & - & 23 & & Secondary salinization, & Bunn and Davies 1990, \\
\hline Invertebrates & 73 & - & 2 & - & sedimentation, habitat loss. & Horwitz et al. 2008 , Danks et \\
\hline Annelida & 23 & - & 0 & - & & al. 2011, Davies and Stewart \\
\hline Arachnida & 27 & - & 0 & - & & 2013; B. Cook, unpublished \\
\hline Mollusca & 43 & 1 & 8 & - & & data. \\
\hline $\begin{array}{l}\text { Macrocrustacea } \\
\text { Insecta }\end{array}$ & 273 & - & 13 & - & & \\
\hline Freshwater Fish & 11 & 4 & 1 & 3 & $\begin{array}{l}\text { Salinity, habitat loss, } \\
\text { temperature, barriers }\end{array}$ & $\begin{array}{l}\text { Pusey et al. 1989, Pusey and } \\
\text { Edward 1990, Morgan et al. }\end{array}$ \\
\hline Estuarine fish & 33 & - & - & - & $\begin{array}{l}\text { reduced FW inflows, marine } \\
\text { connection }\end{array}$ & $\begin{array}{l}2011 . \\
\pm 13 \text { spp; Potter and Hyndes } \\
1994, \text { Young and Potter } 2002 \\
\text { Lester et al. } 2014\end{array}$ \\
\hline Amphibians & 24 (frogs only) & 0 & 3 & 1 & $\begin{array}{l}\text { Seasonal shifts in peak } \\
\text { rainfall }\end{array}$ & Danks et al. 2011 \\
\hline Reptiles & 70 & - & 2 & 1 & Habitat loss & Danks et al. 2011 \\
\hline $\begin{array}{l}\text { Birds } \\
\text { (Terrestrial) }\end{array}$ & $\sim 300$ & 2 & 5 & 12 & $\begin{array}{l}\text { Habitat loss, changing } \\
\text { climate. }\end{array}$ & Pizzey 1997, Danks et al. 2011 \\
\hline Mammals & 40 & 12 & 1 & 12 & $\begin{array}{l}\text { Fire, feral predators, } \\
\text { salinization, habitat loss. }\end{array}$ & Danks et al. 2011 \\
\hline Fungi and Lichens & 622 taxa & - & - & - & $\begin{array}{l}\text { Changing climate, fire } \\
\text { regime, habitat loss }\end{array}$ & $\begin{array}{l}\text { Bougher and Syme 1998, } \\
\text { Syme } 2008\end{array}$ \\
\hline Vascular plants & 5411 taxa & 297 & 757 & 109 & $\begin{array}{l}\text { Pathogens, fire regimes, } \\
\text { salinization, invasive weeds }\end{array}$ & $\underline{\text { http://florabase.dec.wa.gov. }}$ \\
\hline
\end{tabular}

shifting to increased summer/spring rainfall and a decrease during autumn/winter. The Indian Ocean Climate Initiative (IOCI 2006) predicts that by 2030 rainfall will decrease between 2 and $20 \%$ for southwest Australia while temperatures will increase by 0.5 to $2.0^{\circ}$ C. A decrease in rainfall since the 1970's has been attributed to far fewer troughs and more high-pressure systems across the region (Hope 2006, Timbal et al. 2008, Hope and Ganter 2010). It is difficult to determine whether this is due to natural variability (Cullen and Grierson 2009) or anthropogenic forcing through land clearing or increased greenhouse gases (Bates et al. 2008), but part of the change can be attributed to the enhanced greenhouse effect (IOCI 2006, Bates et al. 2008). Although rainfall has already decreased in the western part of the SCR, rainfall in the central part is unchanged (Australian Government 2015). Climate scenarios for the eastern part of the SCR are uncertain but broad scale modeling suggests a smaller decrease in rainfall than in western areas. However, if high pressure systems continue to increase in frequency (Hope and Ganter 2010), a decline in autumn and winter rainfall is most likely for much of the SCR.

Restructuring of species assemblages may not be as profound for very old landscapes such as the SCR. These community assemblages have a long history of adaptation to changing climatic conditions and an intricate interaction of contributing causes to adaptation that can be taxon specific (Hopper 2009). The flora and fauna of this region has a long history of surviving through multiple major climate shifts particularly in the Miocene, Pliocene, and Pleistocene epochs but with the evolution of diversity across that historical span (Rix et al. 2014). This region has experienced shifts from warm, summer rainfall to the current Mediterranean climates with some cooler drier periods in the Pleistocene (Byrne 2010, Rix et al. 2014). This means the biota has either adapted and diversified, or selectively survived in climate niches that have remained unchanged despite radical shifts in seasonal rainfall patterns and temperature. It is therefore possible that this will happen in the future. Ecological systems are complex and future climate conditions are not easy to predict, so that it is difficult to predict the effects of climate change on biodiversity with confidence. Under possible climate changes scenarios, some species with highly specific habitat or climate requirements may become locally extinct.

Collective changes in environmental conditions suggest that, by 2050 , some areas of the SCR will not be suitable for agriculture (Campbell 2008, Australian Government 2015). Nevertheless, for specific locations, this change will depend on soil type and landscape position (van Gool and Vernon 2005, Ludwig and Asseng 2006). Low yielding areas are likely to revert to either 
pastoralism or carbon offset/conservation plantings. In drier areas with more summer rainfall there could be an increase in perennial pastures, which provide opportunities to reduce secondary salinity. The biggest agricultural affect may be from broader seasonal variability; farmers will need to be tactical (Ludwig and Asseng 2006) and have effective risk management strategies.

Analyses of the vulnerability of rural communities to climate change (Ludwig and Asseng 2006, Nelson et al. 2010) suggest that SCR rural communities have high or moderate adaptive capacity. Therefore, they will be only moderately vulnerable to climate change. Climate change and economic conditions do not appear likely to lead to transformative change in land use by 2050 but there will be opportunities for innovation and small-scale landscape change. Farmers in the SCR currently manage seasonal variability with a range of strategies and many of these could be used to adapt to climate change (Howdon et al. 2008). Strategies used to improve soil moisture retention include minimum tillage, increasing residue cover, and controlled traffic across paddocks (Henriksen et al. 2011, GRDC 2015). Reduced rainfall in some areas may result in increased area and yields in soils prone to waterlogging that are presently too wet for cropping. The future effects of salinity are particularly complex. In some betterrestored SCR catchments where salinization effects are close to equilibrium, increasing aridity may lower the saline ground water table leading to partial reversal of salinity. In contrast, in higher rainfall areas the drying climate may reduce the flushing of salt from the landscape and increase salinity.

\section{BIOTIC AND SOCIAL CONSEQUENCES OF PROJECTED CHANGES}

Fundamental changes are taking place in physical and chemical ecosystem attributes of the SCR as a consequence of changes in land use and climate (Table 2). The social implications of these changes will mostly find expression in the economic sustainability of agricultural and forest industries. There will be both costs and benefits as existing production patterns decline and new opportunities arise. Australian farmers have demonstrated an impressive capacity to respond to both market and environmental opportunities, and it seems likely they will continue to do so in the future. However, the social implications of rural adjustment are as much related to nonmarket values as they are to market values. There are at least six basic elements contributing to the aggregate nonmarket value of an ecological or environmental item including aesthetic, spiritual, social, historic, symbolic, and authenticity values (Throsby 2001). These values relate to the connection with the landscape and a sense of identity and community. Possible effects on human health and well-being are difficult to forecast because of the mobility of the human populations; however, there is a real possibility of an increase in diseases and pathogens that are naturally controlled today (Tong et al 2008). The most significant affects resulting from these changes will influence people's sense of place and community, which in turn influence attitudes to conservation and natural resource management initiatives. A sense of place, community cohesion, and social networks, amongst others, are all central elements of social capital, which have been demonstrated as being important factors in environmental and natural resource management (MacGregor and Cary 2002).
On the net positive side, despite widespread changes to agriculture, farming has proven resilient to changes to environmental and economic conditions and it is expected that it will continue to adapt, partly through technological advances, to expected shifts in soils, moisture, and available crops (Table 2). As environmental issues and priorities change in type and geographic spread, management can be targeted to landscapes, industries, and communities at an early stage. The inclusion of community-based natural resource management in preemptive stages is likely to have significant benefits to management outcomes by increasing the capacity of local communities and industries to manage and adapt. This includes incorporating indigenous knowledge and values into the management of natural areas, which has been shown to have significant benefits both for the community and for NRM (Jackson et al. 2005, Dobbs and Cossart 2010).

\section{ADAPTATION STRATEGIES}

Opportunities for adaptation in the SCR are greater than in many adjacent areas of southwest Australia's biodiversity hotspot. The SCR has a range of rainfall, temperature, and land use. In comparison to the internally draining wheat belt region to the north, there is substantial native vegetation remaining and more opportunities to reduce the effects of salinity in vegetatively restored catchments. Coastal vegetation is almost continuous with the majority protected in conservation areas (Wilkins et al. 2006). A relatively high proportion of the cooler, high rainfall zone is protected in reserves or forest managed for conservation or timber production but interspersed with cleared farming areas.

At least until 2050, under current climate models and markets, agriculture is likely to continue as the main land use. Predictions are for increasing crop yields in the higher rainfall zone because of less waterlogging, and areas of reduced yield in the lower rainfall zone, depending on soil type (van Gool and Vernon 2005). Agriculture in the SCR has been highly adaptive as farmers coped with highly erosive, infertile sandplain soils and dry seasons. Many farmers continued to manage profitable enterprises in the face of decreasing terms of trade, although there has been significant restructuring and farm amalgamation (Tonts 1996). Changing environmental conditions may also provide the opportunity for transforming agricultural systems. Increasing perennial agriculture is important in reducing salinity and adapting to changes in rainfall patterns. For example, opportunities to successfully use native flora in profitable enterprises are being explored (Woodall and Robinson 2003). Enabling farmers to adapt to drier autumns and winters, and a potential increase in spring and summer rain, could thereby improve conservation outcomes. In the longer term one type of land use likely to increase is carbon-offset plantings. There is an opportunity to align carbon storage and conservation objectives by using local, rapidlygrowing species rather than species from outside the region. Measuring the carbon storage and growth rates of a wide range of regional species and developing local agroforestry will be, therefore, an important strategy.

The high rainfall zone of the SCR is likely to serve as a refuge for many species as it has in past periods of aridity, as evidenced by the highly endemic nature of the biota. Although reserves are numerous, there is also a proportion affected by inundation, salinity, excessive nutrients, and urbanization. One of the highest 
Table 2. System-scale responses in the South Coast Region to projected changes in climate and land use.

\begin{tabular}{|c|c|c|}
\hline Ecosystem Component & System-scale Responses & References/Notes \\
\hline Soils & $\begin{array}{l}\text { Fundamental changes to soil biogeochemistry (e.g., nitrification, carbon cycling, } \\
\text { and microorganisms), depending on specific (local) climate and land use; } \\
\text { - Soil drying and increased susceptibility to erosion; } \\
\text { - Further acidification under agriculture, salinization, wind and water erosion, and } \\
\text { water repellence; } \\
\text { - Decreases in soil moisture. Interactions between changes in vegetation, grazers, } \\
\text { and soils. }\end{array}$ & Hughes 2003, 2011 \\
\hline Terrestrial & - Ongoing depletion of populations and threats to species; & Abbott and Le Maitre 2010 \\
\hline Vegetation & $\begin{array}{l}\text { - Increased fire frequency and intensity; } \\
\text { - Miss-match of host-pollinators; } \\
\text { - Altered fire regimes and rainfall patterns will increase susceptibility to fungal } \\
\text { - Increases in summer rainfall will increase spread of fungal pathogens; } \\
\text { - Expansion of species/communities adapted to drier habitats in southwesterly } \\
\text { - direction; }\end{array}$ & \\
\hline $\begin{array}{l}\text { Riparian } \\
\text { Vegetation }\end{array}$ & $\begin{array}{l}\text { - Continuing severe loss of riparian vegetation through clearing and the effects of } \\
\text { secondary salinization, with concomitant effects on stream temperatures, } \\
\text { connectivity, and ecosystem interactions (e.g., via nutrient flows). This is } \\
\text { particularly important given rising temperatures affect native aquatic biota with a } \\
\text { low temperature tolerance range; } \\
\text { - Reduction of allochthonous material, an important source material for aquatic } \\
\text { food webs, in combination with canopy loss, will cause a switch to algal based } \\
\text { aquatic food webs; } \\
\text { - Decreased flows reduce bankfull flows, affecting riparian seed-set and recruitment, } \\
\text { thereby simplifying riparian community composition. }\end{array}$ & Pettit et al. 2001, Davies 2010 \\
\hline Fresh Waters & $\begin{array}{l}\text { - Increased numbers of no-flow events in historically perennial systems; } \\
\text { - Flow regimes fundamentally altered from historic conditions; } \\
\text { - Reduction in extent and number of pool refugia due to drying and warming; } \\
\text { - River fauna and river ecosystem processes subjected to conditions not historically } \\
\text { experienced and therefore not adapted; } \\
\text { - Increase in severe events (e.g., storms and droughts) causing greater erosion and } \\
\text { consequent sedimentation of waterways; } \\
\text { - Loss of aquatic habitat (e.g., sedimentation) and connectivity (during no-flow } \\
\text { periods) will impact on migratory pathways and resource use (habitat, food) for } \\
\text { aquatic fauna; } \\
\text { - New conditions may select for species able to recruit at local scales and tolerant of } \\
\text { low dissolved oxygen (e.g., from pool infilling); } \\
\text { - Increasing salinity in wetlands and shallow lakes; loss of native flora and fauna; } \\
\text { meduction of rainfall may lessen secondary salinization. In the long term, short- to } \\
\text { - Change in aquatic food web structure due to increased light, temperature, and } \\
\text { nutrients; }\end{array}$ & $\begin{array}{l}\text { Davies } 2010 \text {, Beatty et al. } 2011 \text {, } \\
\text { Stewart et al. } 2013\end{array}$ \\
\hline Estuaries/Coastal Zone & $\begin{array}{l}\text { - Because of position in the landscape, estuaries accumulate the effects of upstream } \\
\text { disturbance. Catchment land use, particularly its effect of salinity and nutrient } \\
\text { loads of catchment outflows, will significantly affect South Coast estuaries } \\
\text { through water quality alterations; } \\
\text { - Rising temperatures and reduced rainfall may force western estuaries in the South } \\
\text { Coast region to experience conditions similar to those currently experienced in } \\
\text { warmer/dryer areas further east; } \\
\text { - The ability of the Leeuwin Current to round Cape Leeuwin and remain a coherent } \\
\text { system along the South Coast will continue to decline. The resulting cooler waters } \\
\text { do not sustain tropical species such as Mud Crabs, causing the system to shift to } \\
\text { local species; } \\
\text { - There is a possibility that upwelling will increase as the Leeuwin Current decreases, } \\
\text { stimulating productivity. However, future wind patterns will enhance or suppress } \\
\text { upwelling depending on direction, strength, and persistence; } \\
\text { A major unknown is whether ocean temperatures rise as the Leeuwin Current } \\
\text { declines and upwelling increases. }\end{array}$ & $\begin{array}{l}\text { Potter and Hyndes 1994, Brearley } \\
\text { 2005, Chuwen et al. 2009, } \\
\text { Wernberg et al. } 2011\end{array}$ \\
\hline
\end{tabular}


Ecosystem Resilience

Human Health and Wellbeing

Agriculture

Aquaculture

Culture and Social Values

conservation priorities is, therefore, protecting moist refugia such as wetlands, cool temperate forests, and freshwater rivers. Resilience of systems depends on maintaining a diversity of habitats as well as species within functional groups (Holling and Gunderson 2002). For larger rivers, with headwaters in the drier northern parts of the region, additional planting of native
- Current conservation reserves and catchment management strategies will not protect all vulnerable native species and ecosystems - significant loss of resilience to future changes. Conditions exceed those to which much fauna/flora evolved;

- Possible increased effects of plant soil-borne diseases such as fungal dieback, in areas of increased summer rainfall;

- Increased landscape diversity in reserve design, vegetation communities and farming practices to improve resilience;

- Increased invasions by non-native species.

- A decrease in spread of salinity will have positive effects on depression (and comorbid diseases of heart disease, suicide, and asthma), although other impacts may lead to similar consequences;

- Increases in risk are likely to impact on mental and physical health

- Reduced farm incomes from traditional activities;

- A decrease in rural populations as farms become larger will increase isolation of farm families, and will result in reduced human and social capital, which will lower the capacity of farmers to address natural resource management issues and adjust to sustainable management practices;

- There is a possibility that increasing social isolation will result in increased mental health issues;

- Increase in Ross River Virus carrying mosquitoes in saline biodiversity poor areas, but impact on humans minimal because of low population densities;

- Any decrease in native biodiversity or change in ecosystem could potentially pose a disease risk (e.g., Lyme disease or Hanta virus in U.S.);

- Depending on land-use changes, increases in airborne dust will increase lung and eye problems.

- Land managers already adapting to variable weather patterns;

- Increased atmospheric $\mathrm{CO}_{2}$, together with increased temperatures, may result in higher yields, particularly areas where summer rainfall increases;

- Reduced rainfall may increase areas and yields in waterlogged soils that, at present, are too wet for cropping;

- Temperature increases will reduce frost risk on susceptible sites;

- Areas of decreasing rainfall and poor soils (deep sands) are most vulnerable to degradation and loss of viability; these areas should be targeted for restoration with native species;

- Increase in carbon-offset plantings, conservation plantings;

- Existing botanic diversity creates a unique resource from which "climate ready" crops can be developed; many prospective species occur naturally across climate gradients and have commercial potential with regard to provision of food, essential oils, fodder, and biomass.

- Given no increase in nutrient inputs, slightly increased water temperatures $\left(1-2^{\circ} \mathrm{C}\right)$ could increase primary production and, in turn, increase production rates of specific consumers (e.g., abalone);

- If nutrients increase along with temperature, it is expected that production rates of many recreational and commercial fish will be improved;

- Slight increases in water temperature could increase growth rates of cultured species, thus decreasing grow-out times and, potentially, increasing economic viability of aquaculture operations;

- Warming waters may encourage the spread of pathogens (e.g., Perkinsus spp, dinoflaggelate) to traditional hosts (e.g., abalone, other mollusks), especially where organisms become stressed with environmental change;

- Biosecurity will be affected by the increasing mobility of the human population. Managing the translocation of pathogens (e.g., AVG, Abalone Viral Ganglioneuritis) from infected regions to pristine environments becomes difficult as people frequent more locations including remote habitats.

- Significant landscape and ecosystem changes will impact a variety of human values (e.g., aesthetic, spiritual, social, historic, symbolic, and authentic);

- Continuation of farm amalgamation leading to further depopulation of some inland areas and an increase in coastal urbanisation. Further reduction in services in inland areas and decrease in quality of life.
Horwitz et al. 2008, Byrne 2010, Davies 2010, Prober et al. 2012

MacGregor and Cary 2002, Jardine et al. 2007, 2008, Speldewinde et al. 2009, 2011

Woodall and Robinson 2003, Wu et al. 2008, Woodall et al. 2009, Monjardino et al. 2010

Daly 2004; http://www.fao.org/ fishery/climatechange/en

McKenzie 1994, Tonts 1996, Throsby 2001, MacGregor and Cary 2002 vegetation in the upper catchment can further lower groundwater levels and reduce salinity (Clarke et al. 2002, Bari et al. 2004). Although revegetation will also reduce flow, ecologically it is more important to return rivers to freshwater systems. Tools such as precision conservation could be used to target the protection of wetlands and rivers from salinization as well as unwanted nutrients and sediment (Delgado et al. 2011). 
The Australian government views climate change adaptation as core business for regional NRM organizations (Campbell 2008). This provides the opportunity to plan climate change adaptation in a specific bioregional context integrated with other NRM planning. Strategies for surviving a changing climate in the SCR is most likely to mean adaptation to decreasing rainfall and increasing temperature, but the complexity of interactions between temperatures, rainfall, increased $\mathrm{CO}_{2}$, changes in wind speed and direction, changes in summer rainfall patterns, and increased variability make it difficult to predict effects on species. These climatic changes in turn change photosynthesis, evapotranspiration, and a whole range of biotic interactions at different scales (Prober et al. 2012). Additionally, changes in land use due to human responses to climate change will interact with species responses.

Preserving some of the uniqueness and diversity of the SCR is an essential part of natural resource management as the landscape changes through agriculture and other development. The region is dominated by very old, stable pre-Cambrian landscapes that have resulted in highly nutrient-deficient soils (Hopper 2009). Consequently, plants have developed special adaptations associated with coping with dry, infertile lands through specialized root structures and symbiosis, carnivory, pollination mechanisms, and parasitism (Lambers 2014). However, as a consequence of this specialization the plant communities have a large susceptibility to major disturbances. We suggest it is important to preserve wherever possible, these unique, intact native plant communities for their own sake, for their potential medical or chemical uses and for the development of new food crops from native plants that could be highly valuable in the future.

We suggest that because of the high biodiversity and uniqueness of SCR plants and animals, conservation of intact natural areas within the matrix of agricultural land should be a priority and would provide the most cost effective outcomes for maintaining traditional ecosystem services as well as providing source material for novel plantings in agricultural landscapes. A diversity of approaches, which pay particular attention to specific underlying processes, is required to promote resistance and resilience of native ecosystems to the range of threats and disturbances encountered within the agricultural matrix. Although there needs to be a priority for the retention of existing intact natural areas, in previously cleared, abandoned agricultural land, the creation of revegetated, novel communities (Hobbs et al. 2013) that buffer high value, intact areas of native vegetation from agricultural lands, and provide linkages between intact areas, is an important management strategy in the SCR. It is important because it is generally not feasible to re-establish the entire original plant community on abandoned cleared farmland, because of the very high diversity of plants and changed soil and hydrology (Cramer et al. 2008, Standish et al. 2006, 2007, 2008). Therefore, these newly established novel ecosystems would comprise a subset of species from the intact areas and therefore contain species that have the capacity to exploit the demanding climate and soil properties of the region. These replanted areas can also provide habitat for biota and enhance species diversity at landscape scales.

\section{Social-ecological approaches to environmental change}

Successful adaptation to a changing environment requires identification and adoption of common visions at local and regional levels (Table 3 ) along with strategic efforts to meet the visions in an adaptive management framework (Naiman 2013). One vitally important principle is to maintain maximum adaptive capacity in the system and flexibility in management (Millar et al. 2007). There are a number of other general principles developed for adaptation to climate change (see, for example, Hannah et al. 2002, Mawdsley et al. 2009, West et al. 2009). For example, one option is to establish networks that include protected areas, connecting zones, and intermediate landscapes having various uses (Opdam and Wascher 2004) to maintain landscape values and connectedness. Although the climate gradient from northeast to southwest in the SCR is potentially an important refuge route for some species, protecting potential refugia across the whole region and developing a landscape with maximum adaptive capacity provides opportunities for other species.

Successful adaptation to climate change requires identification and adoption of common visions at local and regional levels along with strategic efforts to meet the visions in an adaptive management framework. Importantly, strategic efforts and actions are successful when the understanding, motivation, and capacity of those directly and indirectly involved with the environmental and natural resource management responses are enhanced (Naiman 2013). Clearly implicit in this strategy is the involvement of most stakeholders. The respective level of engagement with stakeholders should reflect their level of investment in the system, whether the investments are financial and/or emotional. Learning acquired by stakeholders involved with strategic action, i.e., planning and management initiatives, allows adaptation to take place, thereby improving the understanding of fundamental challenges (Figure 2). It is vital to consider the elements in Figure 2, e.g., profitability, land tenure, education, skills, and networks, because they contribute to stakeholders' understanding, motivation, and adaptive capacity.

Fig. 2. Interactions and drivers of change for strategic change in natural resource management systems (C. J. MacGregor, unpublished manuscript).

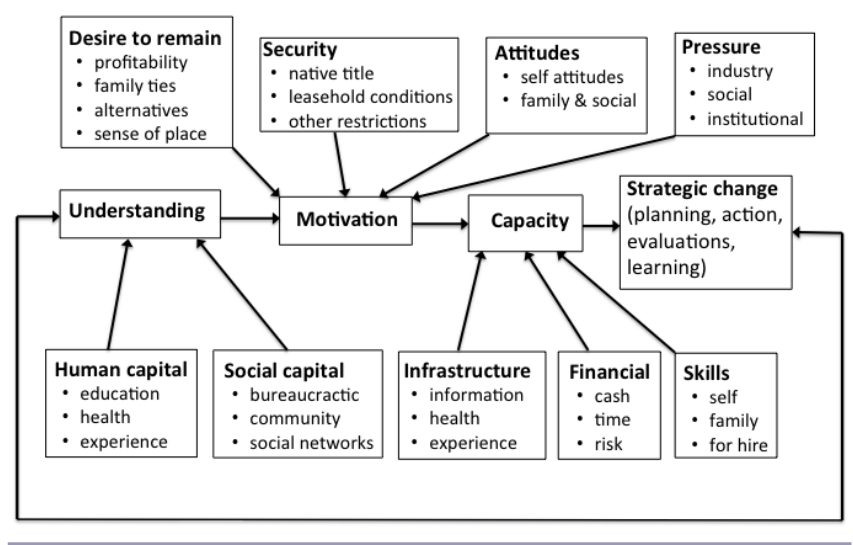

There are general principles and social-ecological approaches that can be applied to the SCR to manage natural resources in a manner that maintains communities in a changing environment (Table 3). The emphasis is on accepting the need to use dynamic, integrated approaches with strong partnerships and continuous monitoring and research. The SCR has highly networked subregional and catchment groups, and specific commitments in 
Table 3. Ideas for maintaining and improving natural resources in the South Coast Region under projected climate and land-use changes.

\begin{tabular}{l}
\hline General Principle \\
Maintain maximum adaptive capacity in biological systems and be \\
prepared for surprise and threshold effects (Millar et al. 2007) \\
Use dynamic conservation approaches (West et al. 2009); allow for \\
nonlinear dynamics
\end{tabular}

\section{Protect Moist Refugia}

Continuous monitoring

Statistical downscaling of Global Climate Models to regional and local scale

Integrated approach to threats

Maintain a mosaic of landscapes and ensure areas outside reserves are protected

Avoid maladaptation

Increase adaptive capacity in the community (MacGregor and Cary 2002; C. J. MacGregor, unpublished manuscript)

Manage transformation (West et al. 2009)

Support research to develop innovative approaches
Approaches

- Maintaining existing areas of native vegetation.

- Collecting and banking seed from climatic ranges.

- Incorporating climate change into management plans for reserves (Hannah et al. 2002).

- Establish thresholds of potential concern (Biggs and Rogers 2003).

- Plan for various scenarios (Peterson et al. 2003).

- Regional modeling of biodiversity response to climate change (Hannah et al. 2002).

- Bioclimatic modeling to create new protected areas (Pyke et al. 2005).

- Practice adaptive management (Millar et al. 2007).

- Increase flexibility with increase in focus on protecting biodiversity outside reserves. Focus on ecological processes.

- Focusing more conservation attention on the high rainfall zone and wetlands.

- Decommissioning drainage areas and restoring wetlands (Robson et al. 2008).

- Create new freshwater habitats (Robson et al. 2008).

- Revegetation to reverse salinity in wetlands and freshwater systems.

- Manage the impact of coastal urbanization on wetlands.

- Revegetation on northern banks of river reaches to increase shade (Davies 2010).

- Create new protected areas (Hannah et al. 2007).

- Movement of non-native and native species and impacts on ecosystems.

- Characterization and impacts of changes in salinity, rainfall, and temperature on estuaries, rivers, and wetlands.

- Potential ecosystem and land-use changes.

- Changes in crop yields.

- Fire threat frequency and timing.

- Impacts of sea level rise.

- Soil type interactions.

- Impacts on aquatic and hydrological systems.

- Selected species level models (Midgley et al. 2002) and species interaction models.

- Model interactions between fire, fungal pathogens, salinity, feral predators, invasive species, and climate change.

- Interactions between salinity, rainfall, and temperature on freshwater systems.

- Encouraging farmers to diversify their landholdings across climatic zones in the agricultural area as a risk strategy, rather than managing single large farms.

- Increasing protection of vegetation outside reserves (e.g., Gondwana Link).

- Appropriately connecting wetlands, threatening endemics.

- Appropriate hydrological engineering.

- Positive translocation of species.

- Establishing successful priorities (triage approach).

- Develop natural resource networks and partnerships through organizations such as South Coast natural resource management (NRM), Gondwana Link, UNESCO Man and the Biosphere Programme.

- Planning adaptation as an opportunity for shared learning (Adger 2003, Cohen 2011).

- Develop regional champions (Cohen 2011).

- Maintain ecosystem functions/services.

- Use the UNESCO Fitzgerald Biosphere Region (in the central part of the region) as a focus for research on climate change and sustainable development.

- Increase research and monitoring in government funded NRM.

- Develop innovative perennial farming systems. 
NRM strategies to increase regional capacity for change. It also has a farming sector well acquainted with innovation and adaptation. Two of the actions listed in Table 3 provide examples of NRM strategies to increase regional capacity, which include the Gondwana Link Project (http://www.gondwanalink.org) and the use of native flora as an adaption to climate change.

The Gondwana Link Project is reconnecting fragmented habitat and increasing the opportunity for encouraging the movement of species along a broad northeast to southwest corridor. Gondwana Link Pty Ltd is a nonprofit group aiming to create landscape scale change by creating "connected and functional landscapes." The Gondwana Link Project groups, Bush Heritage Australia, and Greening Australia are actively purchasing rural properties that, as of 2014, totaled over 7000 ha. Although the properties purchased have been substantially cleared for agriculture, large areas of native vegetation with high conservation values remain. In these areas, intact vegetation requires ongoing protection while planning and monitoring of commercial revegetation of cleared areas ensures plantings also attempt to address biodiversity needs (Hallett et al. 2014, Standish and Hulvey 2014, Perring et al. 2015). The purchase of properties and revegetation with local native plants are designed to connect the Fitzgerald River National Park with the Stirling Range National Park over a distance of $\sim 100 \mathrm{~km}$.

\section{Native flora opportunities}

The Southwest Botanical Province with its high level of diversity and endemism creates a unique resource from which "climate ready" crops could be developed because many prospective species occur naturally across climate gradients (Table 4). In some instances there is a need for commercial drivers for revegetation (Bathgate and Pannell 2002), and a number of the native plants found in Western Australia have commercial potential with regard to the provision of food (Woodall et al. 2009), essential oils (Woodall and Robinson 2003), fodder (Monjardino et al. 2010), and biomass ( $\mathrm{Wu}$ et al. 2008). For instance, with less winter rainfall and an increase in summer rainfall (Hennessy et al. 2007), native sandalwood (Santalum spicatum) is well suited to the forecasted climate changes because it occurs in regions of Western Australia receiving both winter and summer dominated rainfall. Indeed all species listed in Table 4 naturally occur in regions where the reliability of winter rainfall is less certain and there is some summer rainfall. In many areas the strategic use of deep-rooted perennial crops on agricultural land, e.g., lucerne (Medicago sativa), oil mallees (Eucalyptus spp), and sandalwood, can also be important to maintain hydrologic balance and reduce the effects of secondary salinity. Although there are numerous knowledge gaps in terms of quantifying the ecological services that each of the "climate ready" native crops provides now and into the future, the cultivation of perennial tree crops is one means of increasing habitat diversity within cleared agricultural landscapes while still providing long-term income (Hobbs et al. 2003). The biodiversity values associated with the cultivation of mallee trees (Smith 2009), sandalwood, and Melaleuca species (Gove 2012) on cleared agricultural land provide successful examples.

\section{CONCLUSIONS}

In the face of uncertainty and lack of knowledge there is a need to develop social-ecological resilience via diversity throughout the landscape. This suggests that for biodiversity globally there is a need to manage for the persistence of existing diversity as well as for ongoing evolution and human-driven alterations, and to integrate the social and political environments into these processes. Supporting resilience of agricultural enterprises as well as the ecological components of native biodiversity is crucial for effective resource management (Barthel et al. 2013, Marshall and Stokes 2014).

Table 4. Native species with commercial potential for catchments altered by climate change.

\begin{tabular}{|c|c|c|c|}
\hline Species & Product & $\begin{array}{c}\text { Natural } \\
\text { rainfall }(\mathrm{mm})^{\dagger}\end{array}$ & Scale $^{\ddagger}$ \\
\hline $\begin{array}{l}\text { Kennedia } \\
\text { prostrata }\end{array}$ & $\begin{array}{l}\text { fodder/nitrogen } \\
\text { supply }\end{array}$ & $250-800$ & $\begin{array}{l}\text { large }>1 \\
\text { million ha }\end{array}$ \\
\hline $\begin{array}{l}\text { Santalum } \\
\text { spicatum }\end{array}$ & $\begin{array}{l}\text { timber/fragrant } \\
\text { oils, seed oils }\end{array}$ & $200-600$ & small 50,000 ha \\
\hline $\begin{array}{l}\text { Platysace } \\
\text { deflexa }\end{array}$ & $\begin{array}{l}\text { food: root } \\
\text { vegetable }\end{array}$ & $350-550$ & $\begin{array}{l}\text { very small < } \\
100 \text { ha }\end{array}$ \\
\hline $\begin{array}{l}\text { Eucalyptus } \\
\text { loxophleba }\end{array}$ & $\begin{array}{l}\text { biomass/ } \\
\text { eucalyptus oil }\end{array}$ & $200-450$ & $\begin{array}{l}\text { medium } \\
100,000 \text { ha }\end{array}$ \\
\hline
\end{tabular}

'mean annual rainfall distribution.

${ }^{\ddagger}$ Scale of climate ready industry.

If left unchecked, the present commodity system will continue to result in the erosion of the resource base, increasing environmental degradation and continuing social decline. This is exacerbated by differences in power between those who make decisions about commodity production and biodiversity management, and those who are affected by its outcomes. Adaptive capacity, generated through interactions between the social-economic system and the ecological system, is a pillar of NRM; it requires willingness, capacity, and understanding to make a difference to NRM outcomes (Gallopin 2002). The first step is the prevention of further loss or degradation of high-value natural areas. This may be accomplished through policy interventions, awareness raising initiatives, and incentives schemes that integrate social-ecological thinking into conservation planning. This also requires an iterative and flexible process of negotiation, decision-making, and reevaluation, one informed by science but shaped by human values and aspirations (Sayers et al. 2013).

Success in NRM has a no definitive endpoint, but is ongoing and requires continued monitoring, knowledge adoption, communication, and cooperation. This requires commitment by institutions and communities to provide the governance needed for broad collaboration and effective integration across sciencemanagement disciplines as well as across social, political, and ecological boundaries. The adoption of new policies and markets, such as accounting for environmental degradation and carbon storage, will build in the real costs to society of environmental degradation and NRM. This also requires a shift in thinking toward resolving trade-offs, as well as facilitating synergies between conservation and economic interests. Adding flexibility and renewable structures to property rights that can be adapted to incorporate social and environmental objectives (Young and McCay 1995) and payments or tax incentives for better land stewardship, including natural resource and economic goals (Sawin et al. 2003), would be positive steps toward an integrated social-ecological perspective. 
Importantly, strategic efforts and actions are successful when the understanding, motivation, and capacity of those directly and indirectly involved with natural resource management responses are enriched. Clearly, implicit in this is the involvement of stakeholders, and the respective level of engagement with stakeholders should reflect their level of investment in the system, whether this is financial and/or emotional (Naiman 2013). Learning acquired by being involved with strategic action (planning and management initiatives) allows adaptation (sustains adaptive capacity) to take place that improves understanding of the challenges (Fig. 2). We suggest that the best outcomes for natural resource management are through partnerships between community groups, state, and federal resource managers and research organizations such as universities. This provides synergies of local knowledge and capability, management and environmental monitoring, and research. Above all it requires forward and flexible thinking, hence the importance of research, community involvement, and being prepared for unexpected outcomes.

Responses to this article can be read online at: http://www.ecologyandsociety.org/issues/responses. $\mathrm{php} / 7727$

\section{Acknowledgments:}

The authors thank Professor Steve Hopper for reviewing the manuscript and for his valuable suggestions for improvement. We also thank two anonymous referees for their valuable comments. The UWA Institute for Advanced Studies provided support for Professor Naiman to visit Albany, through the 'Professor-at-Large' programme.

\section{LITERATURE CITED}

Abbott, I., and D. LeMaitre. 2010. Monitoring the impact of climate change on biodiversity: the challenge of megadiverse Mediterranean climate ecosystems. Austral Ecology 35:406-422. http://dx.doi.org/10.1111/j.1442-9993.2009.02053.x

Adger, W. N. 2003. Social capital, collective action, and adaptation to climate change. Economic Geography 79:387-404. http://dx.doi.org/10.1111/j.1944-8287.2003.tb00220.x

Allison, H. E., and R. J. Hobbs. 2004. Resilience, adaptive capacity, and the "Lock-in Trap" of the Western Australian agricultural region. Ecology and Society 9(1): 3. [online] URL: http://www.ecologyandsociety.org/vo19/iss1/art3

Australian Government. 2015. Climate change in Australia. CSIRO, Department of Environment and Bureau of Meteorology, Melbourne, Australia. [online] URL: http://www. climatechangeinaustralia.gov.au

Bari, M. A., G. W. Mauger, R. N. M. Dixon, L. H. Boniecka, B. Ward, T. Sparks, and A. M. Waterhouse. 2004. Salinity situation statement: Denmark River. Department of Environment, Water Resource Technical Series No. WRT 30, Perth Western Australia.

Barthel, S., C. L. Crumley, and U. Svedin. 2013. Biocultural refugia: combating the erosion of diversity in landscapes of food production. Ecology and Society 18(4): 71. http://dx.doi. org/10.5751/es-06207-180471

Bates, B. C., P. Hope, B. Ryan, I. Smith, and S. Charles. 2008. Key findings from the Indian Ocean Climate Initiative and their impact on policy development in Australia. Climatic Change 89:339-354. http://dx.doi.org/10.1007/s10584-007-9390-9

Bathgate, A., and D. J. Pannell. 2002. Economics of deep-rooted perennials in Western Australia. Agricultural Water and Management 53:117-132. http://dx.doi.org/10.1016/s0378-3774 (01)00160-3

Beard, J. S. 1980. Vegetation survey of Western Australia. 1:250,000 Series. Vegmap, Perth, Western Australia.

Beatty, S. J., D. L. Morgan, M. Rashnavadi, and A. J. Lymbery. 2011. Salinity tolerances of endemic freshwater fishes of southwestern Australia: implications for conservation in a biodiversity hotspot. Marine and Freshwater Research 62:91-100. http://dx. doi.org/10.1071/MF10100

Beresford, Q., H. Beckle, J. Mulcock, and H. Phillips. 2001. The salinity crisis: landscapes, communities and politics. University of Western Australia Press, Perth, Western Australia.

Biggs, H. C., and K. H. Rogers. 2003. An adaptive system to link science, monitoring and management in practice. Pages 59-80 in J. T. du Toit, K. H. Rogers, and H. C. Biggs, editors. The Kruger experience: ecology and management of savanna heterogeneity. Island Press, Washington, D.C., USA.

Bougher, N. L. and K. Syme. 1998. Fungi of Southern Australia. University of Western Australia Press, Perth, Western Australia.

Brearley, A. 2005. Swanland: estuaries and coastal lagoons of south-western Australia. University of Western Australia Press, Perth, Western Australia.

Bunn, S. E, and P. M. Davies. 1990. Why is the stream fauna of south-western Australia so impoverished? Hydrobiologia 194:169-176. http://dx.doi.org/10.1007/BF00028418

Byrne, M. 2008. Evidence for multiple refugia at different time scales during Pleistocene climatic oscillations in southern Australia inferred from phylogeography. Quaternary Science Reviews 27:2576-2585. http://dx.doi.org/10.1016/j.quascirev.2008.08.032

Byrne, M. 2010. Species response to climate change - can the past inform the future? Department of Environment and Conservation (Science Division) Information Sheet 36/2010, Perth, Western Australia.

Campbell, A. 2008. Managing Australian landscapes in a changing climate: a climate change primer for regional natural resource management bodies. Australian Government, Department of Climate Change, Canberra, Australia.

Cheng, A. S., L. E. Kruger, and S. E. Daniels. 2003. "Place" as an integrating concept in natural resource politics: propositions for a social science research agenda. Social and Natural Resources 16:87-104. http://dx.doi.org/10.1080/08941920309199

Chuwen, B. M., S. D. Hoeksema, and I. C. Potter. 2009. The divergent environmental characteristics of permanently-open, seasonally-open and normally-closed estuaries of south-western Australia. Estuarine, Coastal and Shelf Science 85:12-21. http:// dx.doi.org/10.1016/j.ecss.2009.03.030 
Clarke, C. J., R. J. George, R. W. Bell, and T. J. Hatton. 2002. Dryland salinity in south-western Australia: its origins, remedies, and future research directions. Australian Journal of Soil Research 40:93-113. http://dx.doi.org/10.1071/SR01028

Close, P. G. 2007. Water requirements for estuaries: relationships between freshwater flows, hydrodynamics and larval fish dynamics in estuarine lagoon, south-western Australia. Dissertation. The University of Western Australia, Perth, Australia.

Cohen, S. J. 2011. Overview: climate change adaptation in rural and resource-dependent communities. Pages 401-412 in J. D. Ford and L. Berrang-Ford, editors. Climate change adaptation in developed nations: from theory to practice. Advances in Global Change Research series, Volume 42. Springer, Dordrecht, The Netherlands. http://dx.doi.org/10.1007/978-94-007-0567-8 29

Collard, L. 2006. The cosmology: the creator of the trilogy Waakal ir Nyungar Rainbow Serpent. Pages 121-130 in M. Leybourne and A. Gaynor, editors. Water: histories, cultures, ecologies. University of Western Australia Press, Perth, Western Australia.

Commonwealth Scientific and Industrial Organisation (CSIRO). 2007. Climate change in Australia. Technical Report 2007. CSIRO, Canberra, Australia. [online] URL: http://www.climatechangeinaustralia. gov.au

Cramer, V. A., R. J. Hobbs, R. J. Standish. 2008. What's new about old fields? Land abandonment and ecosystem assembly. Trends in Ecology and Evolution 23:104-112. http://dx.doi.org/10.1016/j. tree.2007.10.005

Cullen, L. E., and P. F. Grierson. 2009. Multi-decadal scale variability in autumn-winter rainfall in south-western Australia since $1655 \mathrm{AD}$ as reconstructed from tree rings of Callitris columellaris. Climate Dynamics 33:433-444. http://dx.doi. org/10.1007/s00382-008-0457-8

Daly, T. 2004. Summary of Proceedings from the Perkinsus Workshop held at the Cronulla Fisheries on 3 September 2003. NSW Fisheries Report Series 10. Sydney, Australia.

Danks, A., M. Spencer, S. Comer, D. Utber, and J. Lockhart. 2011. South Coast biodiversity: an overview of biodiversity values and threats in the South Coast Region. Department of Conservation and Land Management, Albany, Western Australia.

Davies, P. M., 2010. Climate change implications for river restoration in global biodiversity hotspots. Restoration Ecology 18:261-268. http://dx.doi.org/10.1111/j.1526-100X.2009.00648. $\underline{\mathrm{x}}$

Davies, P. M., and B. A. Stewart. 2013. Aquatic biodiversity in the Mediterranean climate rivers of southwestern Australia. Hydrobiologia 719:215-235. http://dx.doi.org/10.1007/s10750-013-1600$\underline{\mathrm{Z}}$

Delgado, J. A., R. Khosla, and T. Mueller. 2011. Recent advances in precision (target) conservation. Journal of Soil and Water Conservation 66:167A-170A. http://dx.doi.org/10.2489/jswc.66.6.167A

Dobbs, R. J., and R. A. Cossart. 2010. Development and trial of a waterways education program for the Kimberley - Process Evaluation and Review. Report to Rangelands NRM Inc., Centre of Excellence in Natural Resource Management, CENRM report
12/09, The University of Western Australia, Perth, Western Australia.

Donovan, S. M., C. Looney, T. Hanson, Y. Sánchez de León, J. D. Wulfhorst, S. D. Eigenbrode, M. Jennings, J. JohnsonMaynard, and N. A. Bosque Pérez. 2009. Reconciling social and biological needs in an endangered ecosystem: the Palouse as a model for bioregional planning. Ecology and Society 14(1): 9. [online] URL: http://www.ecologyandsociety.org/vol14/iss1/ art9/

Framenau, V. W., M. L. Moir, and M. S. Harvey 2008. Terrestrial invertebrates of the South Coast NRM Region of Western Australia: short-range endemics in Gondwanan relictual habitats. Western Australian Museum, Perth, Western Australia.

Gallopin, G. C. 2002. Planning for resilience: scenarios, surprises, and branch points. Pages 361-395 in L. H. Gunderson and C. S. Holling, editors. Panarchy: understanding transformations in human and natural systems. Island Press, Washington, D. C., USA.

George, R., D. McFarlane, and B. Nulsen. 1997. Salinity threatens the viability of agriculture and ecosystems in Western Australia. Hydrogeology Journal 5:6-21. http://dx.doi.org/10.1007/s100400050103

Gilfillan, S. 2000. Terrestrial fauna of the South Coast - a review. South Coast Management Group, Albany, Western Australia.

Gioia, P. 2010. South Coast NRM Region - flora summary. Department of Environment and Conservation, Western Australia, Perth, Western Australia.

Gove, A. 2012. The habitat value of indigenous perennial tree crop systems in the Western Australian wheatbelt. Report for Avongro Wheatbelt Tree Cropping and Lotteries West, Curtin University, Perth, Western Australia.

Grains Research and Development Corporation (GRDC). 2015. Non-wetting soils. GRDC, Canberra, Australia. [online] URL: http://www.grdc.com.au/Research-and-Development/Major-Initiatives/ Non-wetting-soils

Hallett, L. M., R. J. Standish, J. Jonson, R. J. Hobbs. 2014. Seedling emergence and summer survival after direct seeding for woodland restoration on old fields in south-western Australia. Ecological Management \& Restoration 15:140-146. http://dx.doi. org/10.1111/emr.12110

Hannah, L., G. Midgley, S. Andelman, M. Araújo, G. Hughes, E. Martinez-Meyer, R. Pearson, and P. Williams. 2007. Protected area needs in a changing climate. Frontiers in Ecology and the Environment 5:131-138. http://dx.doi.org/10.1890/1540-9295 (2007)5[131:PANIAC]2.0.CO;2

Hannah, L., G. F. Midgley, T. Lovejoy, W. J. Bond, M. Bush, D. Scott, and F. I. Woodward. 2002. Conservation of biodiversity in a changing climate. Conservation Biology 16:264-268. http://dx. doi.org/10.1046/j.1523-1739.2002.00465.X

Hennessy, K. B., B. C. Fitzharris, P. Bates, N. Harvey, S. M. Howden, L. Hughes, J. Salinger, and R. Warrick. 2007. Australia and New Zealand. Pages 504-507 in M. L. Parry, O. F. Canziani, J. P. Palutikof, P. J. van der Linden, and C. E. Hanson, editors. Climate change 2007: impacts, adaptation and vulnerability. Contribution of Working Group II to the Fourth Assessment 
Report of the Intergovernmental Panel on Climate Change. Cambridge University Press, Cambridge, UK.

Henriksen, C. B., K. Hussey, and P. E. Holm. 2011. Exploiting soil-management strategies for climate mitigation in the European Union: maximizing "win-win" solutions across policy regimes. Ecology and Society 16(4): 22. http://dx.doi.org/10.5751/ ES-04176-160422

Hill, N., H. Zhang, T. Trezise, J. Young, N. Moyes, L. Carslake, R. McTaggart, N. C. Turner, W. Anderson, and M. Poole. 2005. Successful cropping in the high rainfall zone of Western Australia. Bulletin 4661 GRDC, CSIRO, and Department of Agriculture Western Australia, Perth, Western Australia.

Hobbs, R., P. C. Catling, J. C. Wombey, M. Clayton, L. Atkins, and A. Reid. 2003. Faunal use of bluegum (Eucalyptus globulus) plantations in southwestern Australia. Agroforestry Systems 58:195-212. http://dx.doi.org/10.1023/A:1026073906512

Hobbs, R. J., E. S. Higgs, and C. Hall, editors. 2013. Novel ecosystems: intervening in the new ecological world order. John Wiley \& Sons, Oxford, UK. http://dx.doi.org/10.1002/9781118354186

Holling, C. S., and L. H. Gunderson. 2002. Resilience and adaptive cycles. Pages 293-313 in L. H. Gunderson and C. S. Holling, editors. Panarchy: understanding transformations in human and natural systems. Island Press, Washington, D.C., USA.

Hope, P. K. 2006. Projected future changes in synoptic systems influencing southwest Western Australia. Climate Dynamics 26:765-780. http://dx.doi.org/10.1007/s00382-006-0116-X

Hope, P., and C. Ganter. 2010. Recent and projected rainfall trends in south-west Australia and the associated shift in weather systems. Pages 53-63 in I. Jubb, P. Holper, and W. Cai, editors. Managing climate change: papers from the Greenhouse 2009 Conference. CSIRO, Collingwood, Victoria, Australia.

Hopper, S. D. 2009. OCBIL theory: towards an integrated understanding of the evolution, ecology and conservation of biodiversity on old, climatically buffered, infertile landscapes. Plant and Soil 322:49-86. http://dx.doi.org/10.1007/s11104-009-0068-0

Hopper, S. D., and P. Gioia. 2004. The southwest Australian floristic region: evolution and conservation of a global hot spot of biodiversity. Annual Review of Ecology, Evolution, and Systematics 35:623-650. http://dx.doi.org/10.1146/annurev. ecolsys.35.112202.130201

Horwitz, P., D. Bradshaw, S. Hopper, P. Davies, R. Froend, and F. Bradshaw. 2008. Hydrological change escalates risk of ecosystem stress in Australia"s threatened biodiversity hotspot. Journal of the Royal Society of Western Australia 91:1-11.

Howdon, S. M., R. G. Gifford, H. Meinke, and Farmer Respondents. 2008. 'Grains.' Pages 43-70 in An overview of climate change adaptation in Australian primary industries-impacts, options and priorities. Report prepared for the National Climate Change Research Strategy for Primary Industries. CSIRO, Canberra, Australia.

Hughes, L. 2003. Climate change and Australia: trends, projections and impacts. Austral Ecology 28:423-443. http://dx. doi.org/10.1046/j.1442-9993.2003.01300.x
Hughes, L. 2011. Climate change and Australia: key vulnerable regions. Regional Environmental Change 11 (Suppl 1):S189-S195. http://dx.doi.org/10.1007/s10113-010-0158-9

Indian Ocean Climate Initiative (IOCI). 2006. IOCI Stage 2: reports of phase 2 activity January 2005 - June 2006. IOCI, Perth, Western Australia. [online] URL: http://www.ioci.org.au/ publications/ioci-stage-2/cat_view/16-ioci-stage-2/22-reports/35-researchreports.html

Intergovernmental Panel on Climate Change (IPCC). 2014. Summary for policymakers. Pages 1-32 in C. B. Field, V. R. Barros, D. J. Dokken, K. J. Mach, M. D. Mastrandrea, T. E. Bilir, M. Chatterjee, K. L. Ebi, Y. O. Estrada, R. C. Genova, B. Girma, E. S. Kissel, A. N. Levy, S. MacCracken, P. R. Mastrandrea, and L. L. White, editors. Climate change 2014: impacts, adaptation, and vulnerability. Part A: global and sectoral aspects. Contribution of Working Group II to the Fifth Assessment Report of the Intergovernmental Panel on Climate Change. Cambridge University Press, Cambridge, UK.

Jackson, S., M. Storrs, and J. Morrision. 2005. Recognition of Aboriginal rights, interests and values in river research and management: perspectives from northern Australia. Ecological Management \& Restoration 6:105-110. http://dx.doi.org/10.1111/ j.1442-8903.2005.00226.x

Jardine, A., P. Speldewinde, S. Carver, and P. Weinstein. 2007. Dryland salinity and ecosystem distress syndrome: human health implications. Ecohealth 4:10-17. http://dx.doi.org/10.1007/ s10393-006-0078-9

Jardine, A., P. Speldewinde, M. D. A. Lindsay, A. Cook, C. A. Johansen, and P. Weinstein. 2008. Is there an association between dryland salinity and Ross River Virus disease in southwestern Australia? Ecohealth 5:58-68. http://dx.doi.org/10.1007/s10393-007-0151$\underline{Z}$

Kennard, M. J., B. J. Pusey, J. D. Olden, S. J. Mackay, J. L. Stein, and N. Marsh. 2010. Classification of natural flow regimes in Australia to support environmental flow management. Freshwater Biology 55:171-193. http://dx.doi.org/10.1111/ j.1365-2427.2009.02307.X

Klausmeyer, K. R., and M. R. Shaw. 2009. Climate change, habitat loss, protected areas and the climate adaptation potential of species in Mediterranean ecosystems worldwide. PLOS ONE 4(7):e6392. http://dx.doi.org/10.1371/journal.pone.0006392

Lambers, H., editor. 2014. Plant life on the sandplains in southwest Australia: a global biodiversity hotspot. University of Western Australia Press, Nedlands, Australia.

Lester, R., P. G. Close, J. L. Barton, A. J. Pope, and S. C. Brown. 2014. Predicting the likely response of data-poor ecosystems to climate change using space-for-time substitution across domains. Global Change Biology 20:3471-3481. http://dx.doi.org/10.1111/ gcb. 12634

Lockwood, M., M. Mitchell, S. A. Moore, and S. Clement. 2014. Biodiversity governance and social-ecological system dynamics: transformation in the Australian Alps. Ecology and Society 19(2): 13. http://dx.doi.org/10.5751/ES-06393-190213 
Ludwig, F., and S. Asseng. 2006. Climate change impacts on wheat production in a Mediterranean environment in Western Australia. Agricultural Systems 90:159-179. http://dx.doi.org/10.1016/j. agsy.2005.12.002

MacGregor, C. J., and J. Cary. 2002. Social/human capital rapid appraisal model(SCRAM): a method of remotely assessing social and human capacity in Australian rural communities. Rural Society 12:105-122. http://dx.doi.org/10.5172/rsj.12.2.105

Marshall, N. A., and C. J. Stokes. 2014. Influencing adaptation processes on the Australian rangelands for social and ecological resilience. Ecology and Society 19(2): 14. http://dx.doi. org/10.5751/ES-06440-190214

Mawdsley, J. R., R. O’Malley, and D. S. Ojima. 2009. A review of climate-change adaptation strategies for wildlife management and biodiversity conservation. Conservation Biology 23:1080-1089. http://dx.doi.org/10.1111/j.1523-1739.2009.01264.x

Mayer, X. M., J. K. Ruprecht, and M. A. Bari. 2005. Stream salinity status and trends in south-west Western Australia. Department of Environment, Salinity and Land Use Impacts Series, Report No. SLUI 38, Department of Environment Western Australia, Perth, Western Australia.

McFarlane, D. J., and R. J. George. 1992. Factors affecting dryland salinity in two wheat belt catchments in Western Australia. Australian Journal of Soil Research 30:85-100. http:// dx.doi.org/10.1071/SR9920085

McKenzie, F. 1994. Regional population decline in Australia: impacts and policy implications. Australian Government Publishing Service, Canberra, Australia.

Midgley, G. F., L. Hannah, D. Millar, M. C. Rutherford, and L. W. Powrie. 2002. Assessing the vulnerability of species richness to anthropogenic climate change in a biodiversity hotspot. Global Ecology and Biogeography 11:445-451. http://dx.doi.org/10.1046/ j.1466-822X.2002.00307.X

Millar, C. I., N. L. Stephenson, and S. L. Stephens. 2007. Climate change and the forests of the future: managing in the face of uncertainty. Ecological Applications 17:2145-2151. http://dx.doi. org/10.1890/06-1715.1

Mittermeier, R. A., G. P. Robles, M. Hoffmann, J. Pilgrim, T. Brooks, C. G. Mittermeier, J. Lamoreux, and G. A. B. da Fonseca. 2004. Hotspots revisited: Earth's biologically richest and most endangered ecoregions. Conservation International, Washington, D.C., USA.

Monjardino, M., D. Revell, and D. J. Pannell. 2010. The potential contribution of forage shrubs to economic returns and environmental management in Australian dryland agricultural systems. Agricultural Systems 103:187-197. http://dx.doi. org/10.1016/j.agsy.2009.12.007

Morgan, D. L., S. J. Beatty, M. W. Klunzinger, M. G. Allen, and Q. F. Burnham. 2011. A field guide to freshwater fishes, crayfishes \& mussels of south-western Australia. South East Regional Centre for Urban Landcare, Beckenham, Western Australia.

Moritz, C., and R. Agudo. 2013. The future of species under climate change: resilience or decline? Science 341:504-508. http:// dx.doi.org/10.1126/science. 1237190
Myers, J. S. 1990. Precambian tectonic evolution of part of Gondwana, southwestern Australia. Geology 18:537-540. http:// dx.doi.org/10.1130/0091-7613(1990)018<0537:PTEOPO>2.3.CO;2

Myers, N., R. A. Mittermeier, C. G. Mittermeier, G. A. B. da Fonseca, and J. Kent. 2000. Biodiversity hotspots for conservation priorities. Nature 403:853-858. http://dx.doi.org/10.1038/35002501

Naiman, R. J. 2013. Socio-ecological complexity and the restoration of river ecosystems. Inland Waters 3:391-410. http:// dx.doi.org/10.5268/IW-3.4.667

Nelson, R., P. Kokic, S. Crimp, P. Martin, H. Meinke, S. M. Howden, P. de Voil, and U. Nidumolu. 2010. The vulnerability of Australian rural communities to climate variability and change: Part II-integrating impacts with adaptive capacity. Environmental Science and Policy 13:18-27. http://dx.doi.org/10.1016/j. envsci.2009.09.007

Opdam, P., and C. Wascher. 2004. Climate change meets habitat fragmentation: linking landscape and biogeographical scale levels in research and conservation. Biological Conservation 117:285-297. http://dx.doi.org/10.1016/j.biocon.2003.12.008

Perring, M. P., J. Jonson, D. Freudenberger, R. Campbell, M. Rooney, R. J. Hobbs, and R. J. Standish. 2015. Soil-vegetation type, stem density and species richness influence biomass of restored woodland in south-western Australia. Forest Ecology and Management 344:53-62. http://dx.doi.org/10.1016/j.foreco.2015.02.012

Peterson, G. D., G. S. Cumming, and S. R. Carpenter. 2003. Scenario planning: a tool for conservation in an uncertain world. Conservation Biology 17:358-366. http://dx.doi.org/10.1046/ j.1523-1739.2003.01491.x

Pettit, N. E., R. H. Froend, and P. M. Davies. 2001. Identifying the natural flow regime and the relationship with riparian vegetation for two contrasting WWestern Australian rivers. Regulated Rivers: Research and Management 17:201-215. http:// dx.doi.org/10.1002/rrr.624

Pizzey, G. 1997. A field guide to the birds of Australia. Angus and Robertson, Sydney, Australia.

Potter, I. C., and G. A. Hyndes. 1994. Composition of the fish fauna of a permanently open estuary on the southern coast of Australia, and comparisons with a nearby seasonally closed estuary. Marine Biology 121:199-209. http://dx.doi.org/10.1007/ $\underline{\mathrm{BF} 00346727}$

Prober, S. M., K. R. Thiele, P. W. Rundel, C. J. Yates, S. L. Berry, M. Byrne, L. Christidis, C. R. Gosper, P. F. Grierson, K. Lemson, T. Lyons, C. Macfarlane, M. H. O'Connor, J. K. Scott, R. J. Standish, W. D. Stock, E. J. B. van Etten, G. W. Wardell-Johnson, and A. Watson. 2012. Facilitating adaptation of biodiversity to climate change: a conceptual framework applied to the world's largest Mediterranean-climate woodland. Climatic Change 110:227-248. http://dx.doi.org/10.1007/s10584-011-0092-y

Pusey, B. J., and D. H. D. Edward. 1990. Structure of fish assemblages in waters of the southern acid peat flats, southwestern Australia. Australian Journal of Marine and Freshwater Research 41:721-734. http://dx.doi.org/10.1071/MF9900721

Pusey, B. J., A. W. Storey, P. M. Davies, and D. H. D. Edward. 1989. Spatial variation in fish communities in two south-western 
Australian river systems. Journal of the Royal Society of Western Australia 71:69-75.

Pyke, C. R., S. J. Andelman, and G. Midgley. 2005. Identifying priority areas for bioclimatic representation under climate change: a case study for Proteaceae in the Cape Floristic Region, South Africa. Biological Conservation 125:1-9. http://dx.doi. org/10.1016/j.biocon.2004.08.004

Rix, M. G., D. L. Edwards, M. Byrne, M. S. Harvey, L. Joseph, and J. D. Roberts. 2014. Biogeography and speciation of terrestrial fauna in the south-western Australian biodiversity hotspot. Biological Reviews, in press. http://dx.doi.org/10.1111/brv.12132

Robson, B. J., E. T. Chester, B. D. Mitchell, and T. G. Mathews. 2008. Identification and management of refuges for aquatic organisms. Waterlines Report No.11, National Water Commission, Canberra, Australia.

Sala, O. E., F. S. Chapin III, J. J. Armesto, E. Berlo, J. Bloomfield, R. Dirzo, E. Huber-Sanwald, L. F. Huenneke, R. B. Jackson, A. Kinzig, R. Leemans, D. M. Lodge, H. A. Mooney, M. Osterheld, N. L. Poff, M. T. Sykes, B. H. Walker, M. Walker, and D. H. Wall. 2000. Global biodiversity scenarios for the year 2100. Science 287:1770-1774. http://dx.doi.org/10.1126/science.287.5459.1770

Sawin, B., H. Hamilton, A. Jones, P. Rice, D. Seville, S. Sweitzer, and D. Wright. 2003. Commodity system challenges. Moving sustainability into the mainstream of natural resource economies. Sustainability Institute, Hartland, Vermont, USA.

Sayers, J., T. Sunderland, J. Ghazouf, J. L. Pfund, D. Sheil, E. Meijard, M. Venter, A. K. Boedhihartono, M. Day, C. Garcia, C. Van Oosten, and L. E. Buck. 2013. Ten principles for a landscape approach to reconciling agriculture, conservation, and other competing land uses. Proceeding of the National Academy of Science 110:8349-8356. http://dx.doi.org/10.1073/pnas.1210595110

Scheffers, B. R., T. A. Evans, S. E. Williams, and D. P. Edwards. 2014. Microhabitats in the tropics buffer temperature in a globally coherent manner. Biology Letters 10:20140819. http://dx.doi. org/10.1098/rsbl.2014.0819

Scheffers, B. R., B. L. Phillips, W. F. Laurance, N. S. Sodhi, A. Diesmos, and S. E. Williams. 2013. Increasing arboreality with altitude: a novel biogeographic dimension. Proceedings of the Royal Society B 280:20131581. http://dx.doi.org/10.1098/ rspb.2013.1581

Smith, F. P. 2009. Assessing the habitat quality of oil mallees and other planted farmland vegetation with reference to natural woodland. Ecological Management and Restoration 10:217-227. http://dx.doi.org/10.1111/j.1442-8903.2009.00491.x

Speldewinde, P. C., A. Cook, P. Davies, and P. Weinstein. 2009. A relationship between environmental degradation and mental health in rural Western Australia. Health and Place 15:880-887. http://dx.doi.org/10.1016/j.healthplace.2009.02.011

Speldewinde, P. C., A. Cook, P. Davies, and P. Weinstein. 2011. The hidden health burden of environmental degradation: disease comorbidities and dryland salinity. EcoHealth 8:82-92. http://dx. doi.org/10.1007/s10393-011-0686-X

Standish, R. J., V. A. Cramer, and R. J. Hobbs. 2008. Land-use legacy and the persistence of invasive Avena barbata on abandoned farmland. Journal of Applied Ecology 45:1576-1583. http://dx.doi.org/10.1111/j.1365-2664.2008.01558.x

Standish, R. J., V. A. Cramer, R. J. Hobbs, and H. T. Kobryn. 2006. Legacy of land-use evident in soils of Western Australia's wheatbelt. Plant and Soil 280:189-207. http://dx.doi.org/10.1007/ s11104-005-2855-6

Standish, R. J., V. A. Cramer, S. L. Wild, and R. J. Hobbs. 2007. Seed dispersal and recruitment limitation are barriers to native recolonization of old-fields in Western Australia. Journal of Applied Ecology 44:435-445. http://dx.doi.org/10.1111/ j.1365-2664.2006.01262.x

Standish, R. J., and K. B. Hulvey. 2014. Co-benefits of planting species mixes in carbon projects. Ecological Management \& Restoration 15:26-29. http://dx.doi.org/10.1111/emr.12084

Stewart, B. A. 2009. Two aquatic bioregions for the South Coast Region, Western Australia. Journal of the Royal Society of Western Australia 92:277-287.

Stewart, B. A., P. G. Close, P. A. Cook, and P. M. Davies. 2013. Upper thermal tolerance of key taxonomic groups of stream invertebrates. Hydrobiologia 718:131-140. http://dx.doi.org/10.1007/ s10750-013-1611-9

Syme, K. 2008. Fungi survey of the South Coast Natural Resource Management Region, 2006-2007. Department of Environment and Conservation, Albany, Western Australia

Throsby, D. 2001. Conceptualising Heritage as Cultural Capital. Pages 6-13 in Heritage economics: challenges for heritage conservation and sustainable development in the 21st century. Conference proceedings. Australian Heritage Commission, Canberra, Australia.

Timbal, B., P. Hope, and S. Charles. 2008. Evaluating the consistency between statistically downscaled and global dynamical model climate change projections. Journal of Climate 21:6052-6059. http://dx.doi.org/10.1175/2008JCLI2379.1

Tong, S., P. Dale, N. Nicholls, J. S. Mackenzie, R. Wolff, A. J. McMichael. 2008. Climate variability, social and environmental factors, and Ross River Virus transmission: research development and future research needs. Environmental Health Perspectives 116:1591-1597. http://dx.doi.org/10.1289/ehp.11680

Tonts, M. 1996. Economic restructuring and small town adjustment: evidence from the Western Australian central wheatbelt. Rural Society 6:24-33. http://dx.doi.org/10.5172/ rsj.6.2.24

Van Gool, D., and L. Vernon. 2005. Potential impacts of climate change on agricultural land use suitability: wheat. Resource Management Technical Report 295, Department of Agriculture, Government of Western Australia, Perth, Western Australia.

Wernberg T., B. D. Russell, P. J. Moore, S. D. Ling, D. A. Smale, A. Campbell, M. A. Coleman, P. D. Steinberg, G. A. Kendrick, and S. D. Connell. 2011. Impacts of climate change in a global hotspot for temperate marine biodiversity and ocean warming. Journal of Experimental Marine Biology and Ecology 400:7-16. http://dx.doi.org/10.1016/j.jembe.2011.02.021

West, J. M., S. H. Julius, P. Kareiva, C. Enquait, J. J. Lawler, B. Petersen, A. E. Johnson, and M. R. Shaw. 2009. US natural 
resources and climate change: concepts and approaches for management adaptation. Environmental Management 44:1001-1021. http://dx.doi.org/10.1007/s00267-009-9345-1

Wilkins, P., S. Gilfillan, J. Watson, and A. Sanders, editors. 2006. The Western Australian South Coast Macro Corridor Network - a bioregional strategy for nature conservation. Department of Conservation and Land Management (CALM) and South Coast Regional Initiative Planning Team (SCRIPT), Albany, Western Australia.

Woodall, G. S., M. L. Moule, P. Eckersley, B. Boxshall, and B. Puglisi. 2009. New root vegetables for the native food industry. Rural Industries Research and Development Corporation (RIRDC), Publication No 09/161, Canberra, Australia.

Woodall, G. S. and C. J. Robinson. 2003. The natural diversity of Santalum spicatum host species in south coast river systems and their incorporation into profitable biodiverse revegetation. Australian Journal of Botany 51:741-753 . http://dx.doi. org/10.1071/BT02118

World Health Organization (WHO). 2015. Climate change and human health. WHO, Geneva, Switzerland. [online] URL: http:// www.who.int/globalchange/environment/en/

Wu, H., Q. Fu, R. Giles, and J. Bartle. 2008. Production of Mallee biomass in Western Australia: energy balance analysis. Energy Fuels 22:190-198. http://dx.doi.org/10.1021/ef7002969

Young, G. C., and I. C. Potter. 2002. Influence of exceptionally high salinities, marked variations in freshwater discharge and opening of estuary mouth on the characteristics of the ichthyofauna of a normally-closed estuary. Estuarine, Coastal and Shelf Science 55:223-246. http://dx.doi.org/10.1006/ecss.2001.0899

Young, M. D., and B. J. McCay. 1995. Building equity, stewardship, and resilience into market-based property rights systems. Pages 87-102 in S. Hanna and M. Munasinghe, editors. Property rights and the environment: social and ecological issues. Beijer International Institute of Ecological Economics and the World Bank, Washington, D.C., USA. 